\title{
A Reevaluation of the Late Quaternary Sedimentation in Todos os Santos Bay (BA), Brazil
}

\author{
GUILHERME C. LESSA, ABÍLIO C.S.P. BITTENCOURT, \\ ARNO BRICHTA and JOSÉ M. L. DOMINGUEZ \\ Laboratório de Estudos Costeiros, Centro de Pesquisa em Geofísica e Geologia, \\ Instituto de Geociências, Universidade Federal da Bahia, Campus Ondina, 40210-340 Salvador, BA, Brazil
}

Manuscript received on April 28, 1999; accepted for publication on May 30, 2000;

presented by KENITIRO SUGUIO

\begin{abstract}
Todos os Santos Bay is a large $\left(\simeq 1000 \mathrm{~km}^{2}\right)$, structurally controlled tidal bay in northeast Brazil. Three main drainage basins debouch into the bay, providing a mean freshwater discharge of $200 \mathrm{~m}^{3} / \mathrm{s}$ (prior to 1985), or less than $1 \%$ of the spring tidal discharge through the bay mouth. Based on the result of several sedimentological studies performed in the 1970's, five surface sedimentary facies were identified inside the bay, namely i) transgressive siliciclastic marine sand facies; ii) transgressive bay sand-mud facies; iii) a transgressive carbonate marine sand facies; iv) regressive bay-mud facies, and v) regressive fluvial sand facies. The spatial distribution of these facies would follow, somewhat closely, the hydrodynamic-energy distribution inside the bay. Seismic profiles along the bay bottom indicate the existence of several paleochannels, 5-10 $\mathrm{m}$ deep, blanketed at least by three different sedimentary units. The topmost sedimentary unit, 5-20 m thick, appears to be associated with the regressive bay-mud facies, and assuming that it was laid down within the last 5000 years, sedimentation rates for the central and northeastern part of the bay would average at 2,4 $\mathrm{mm} / \mathrm{y}$.
\end{abstract}

Key words: estuary, sediment, stratigraphy, Holocene.

\section{INTRODUCTION}

The Todos os Santos Bay (TSB) (Figure 1) is the second largest coastal indentation of the Brazilian coast, with an area of approximately $1000 \mathrm{~km}^{2}$. Geological studies in the TSB date back more than 20 years, with an initial characterization of a calcareous shelly bank (Leão 1971). It was followed by several other studies, until the early 80 's, aimed to determine the general sedimentological aspects of the bay and the distribution of the surface sedimentary facies (Bittencourt et al. 1974, Bittencourt \& Vilas Boas 1977, Nascimento 1977, Barros 1977, Leão \&

Correspondence to: Guilherme C. Lessa

E-mail: glessa@pppg.ufba.br
Bittencourt 1977, Avanzo 1977, Brichta 1977, Vilas Boas \& Nascimento 1979, Macedo 1977, Vilas Boas \& Bittencourt 1979, Machado 1977, Leão et al. 1982, Araújo et al. 1984). Investigations on the stratigraphy of the bay are, however, very limited, being restricted to a seismic study by Pasenau and Brichta (1987) on recent tectonic structures.

A recent demand for geological and oceanographical information on the TSB has prompted the reanalysis of published data sets and the recovery of old, unpublished data, such as seismic profiles. This paper intends to present a preliminary analysis of the subsurface geology of the TSB, and along with the knowledge gathered on sedimentation and evo- 


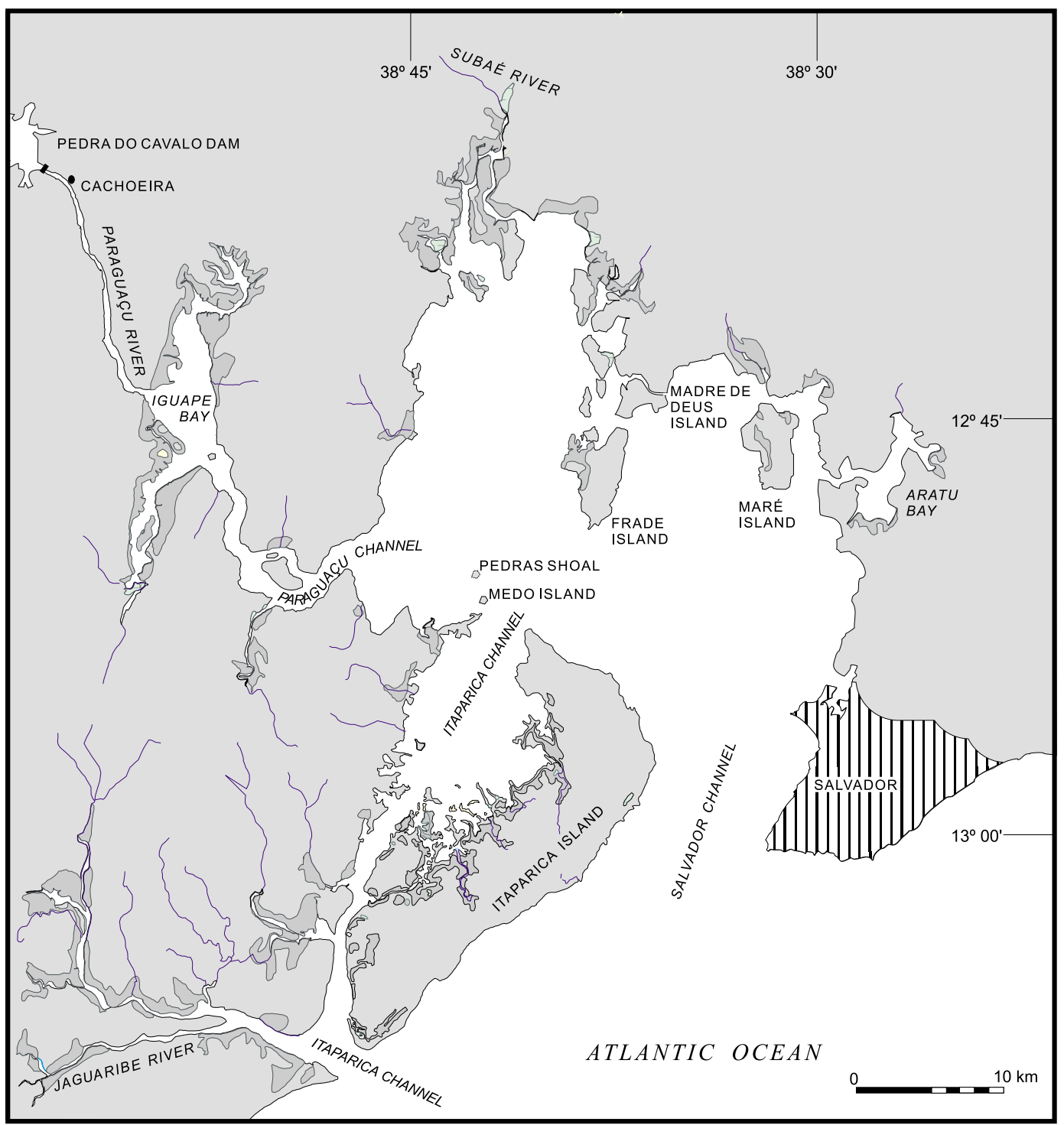

Fig. 1 - Location map of Todos os Santos Bay.

lutionary processes in estuaries in more recent years, propose a new distribution of the sedimentary facies inside the bay.

\section{STUDY AREA}

\section{I Geology and Geomorphology}

The TSB has its origin related to Lower Cretaceous fault lines that formed the Recôncavo Basin (Medeiros \& Ponte 1981) (Figure 2). The basin is delimited by the Salvador and Maragojipe faults, with vertical offsets of 6,000 and $300 \mathrm{~m}$, respectively. The surroundings of the bay are composed of Jurassic and Cretaceous sedimentary rocks excepting for a small area, in the city of Salvador, where the pre-Cambrian basement outcrops along the Salvador Fault (Figure 2). Along the northern and eastern coast, as well as in the various islands inside the bay, Lower Cretaceous shale, siltstone and sandstone (Santo Amaro Group) are the most prominent rocks. At the south- 
western margin and along the Paraguaçu channel, Upper Jurassic red sandstone intercalated with shale (Sergi Formation) predominate until Iguape Bay, where Cretaceous shale and siltstone (Santo Amaro Group) appears in sharp contact with the PreCambrian basement along the Maragojipe fault Quaternary deposits, including alluvial fan, marine terraces and mangrove occur along the margins, especially at the western half of the bay (Figures 1 and 2). Quaternary alluvial fan deposits are restricted to the vicinity of the hills dominated by the Jurassic sandstone (Figure 2).

Sea level studies in the region indicate a Holocene post-glacial marine transgression maximum of about $5 \mathrm{~m}$ at $5.600 \mathrm{cal}$. years B.P. (Martin et al. 1999), being followed since then by a general, albeit controversial, relative sea-level fall (Angulo \& Lessa 1997, Lessa \& Angulo 1998, Martin et al. 1998).

The TSB has two entrances separated by Itaparica Island (Figure 1). The most important is the Salvador Channel, which seems to provide for most of the water exchange between the bay and the ocean (see Lessa et al. in press). Average and maximum channel depths are $25 \mathrm{~m}$ and $102 \mathrm{~m}$, respectively, in relation to the Brazilian Hydrographic Authority's (DHN) datum, henceforth adopted as a reference level $(0 \mathrm{~m} \mathrm{DHN} \approx 1.30 \mathrm{~m}$ below MSL). The Itaparica channel, to the southwest, presents a smoother topography with an average depth of $10 \mathrm{~m}$. Maximum depths inside the TSB are associated with the strait north of Frades Island (over $60 \mathrm{~m}$ ) and the passages to Aratu Bay (30 m) and Iguape Bay (50 m). Iguape Bay receives the discharge from Paraguaçu River (Figure 1), and a major fluvial delta shoals all its central part (Figure 3$)$. Very shallow depths $(<5$ $\mathrm{m})$ characterizes the northern extremity of the TSB.

Well developed ebb tidal deltas in front of both entrances suggest ebb-dominant conditions for most of the bay (see also Lessa et al. in press). Both deltas appear to be associated with the hydraulic barrier imposed on the longshore-sediment drift by the tidal currents exiting the bay, given that sediment exportation appears to be minimum (Lessa et al. in press,
Bittencourt et al. submitted).

Coral reefs border the southeastern side of Itaparica and Frade islands, as well as the southern side of Maré Island (Leão \& Brichta 1996), all exposed to the E-SE swell. This suggests that marine, and not estuarine, conditions exist at least in the eastern half of the TSB (see also Wolgemuth et al. 1981). The non-existence of living coral reefs in the west side of the bay seems to be more related to higher water turbidity than to variations in water temperature or salinity (Z. Leão, Geology Dept. - UFBA, per. comm. 1997).

\subsection{Hydrology / OCEANOGRAPHY}

The climate around the bay is tropical humid, with a ten-year average mean air temperature of $25.3^{\circ} \mathrm{C}$ close to Salvador, and a 30 year mean rainfall of about $1900 \mathrm{~mm} / \mathrm{y}$. Three main watersheds drain into the TSB, namely Paraguaçu, Subaé and Jaguaribe rivers (Figure 1), with long term average discharges of $112 \mathrm{~m}^{3} / \mathrm{s}, 7.7 \mathrm{~m}^{3} / \mathrm{s}$ e $0.32 \mathrm{~m}^{3} / \mathrm{s}$, respectively (CEPLAB 1979, Wolgemuth et al. 1981). The Pedra do Cavalo Dam (Figure 1), built in 1980, greatly diminished the freshwater discharge (Mestrinho 1998, Lessa et al. in press), as well as may have impacted the sediment yield into the bay. The average total freshwater inflow to the bay, prior to the dam, was about 200 times smaller than the average tidal discharge through the mouth, suggesting little influence of the land drainage in the circulation of the TSB (Lessa et al. in press). In fact, salinity and temperature measurements along the main axis of the bay suggest open marine conditions, with estuarine characteristics found only along the Paraguaçu Channel and Paraguaçu River (Wolgemuth et al. 1981). Water circulation inside the TSB appears to be driven primarily by tides, with mostly bi-directional currents prevailing everywhere in the bay (Lessa et al. in press). Average values of suspended sediment concentration in the east and west half of the bay were $1,5 \mathrm{mg} / \mathrm{l}$ and $3,8 \mathrm{mg} / \mathrm{l}$, respectively, and along the Paraguaçu channel these values varied between 10 and 70mg/l (Wolgemuth et al. 1981, Barreto \& Paredes 1995). Vertical profiles of suspended sed- 


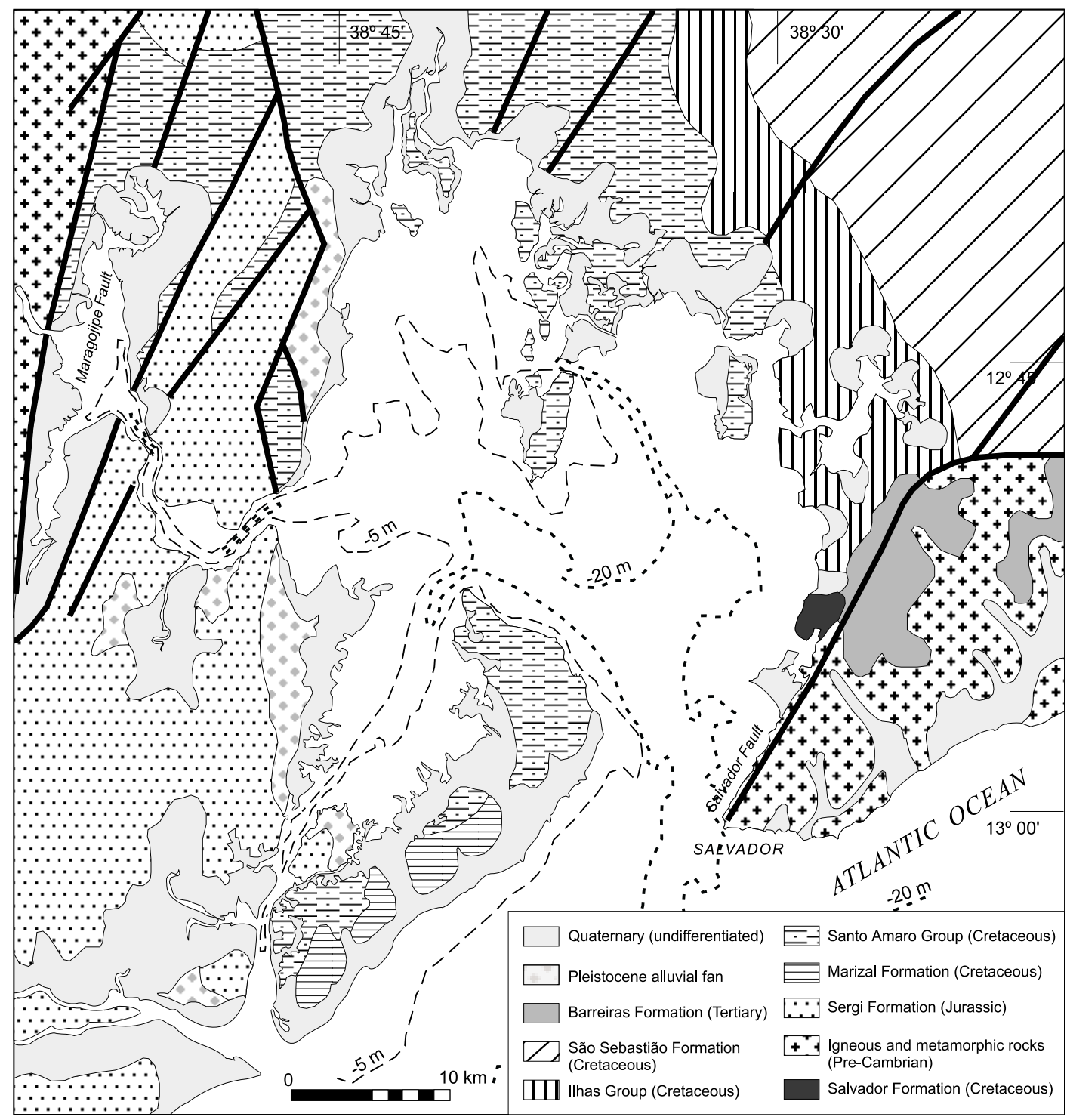

Fig. 2 - Geology map of the surroundings of Todos os Santos Bay (after Medeiros \& Ponte 1981) and the general bathymetric contour of Todos os Santos Bay (source: DHN's nautical chart 1:66:000).

iment concentration showed increasing values with depth, a phenomenon ascribed by Wolgemuth et al. (1981) to sediment resuspension.

\section{DATA SOURCES}

The characteristics of the surface sediments within the TSB derive from the work of Bittencourt et al. (1974) in Aratu Bay, Avanzo (1977) in Iguape Bay,
Brichta (1977) in Paraguaçu Channel, Bittencourt et al. (1976), Macedo (1977) and Vilas Boas and Bittencourt (1979) in the central part of the TSB. Samples were collected with a grab sampler, and positioning was performed with triangulation using a compass and navigation charts. When mapping, interpolation between samples was done assuming that a linear transition between different sediment characteristics existed. 


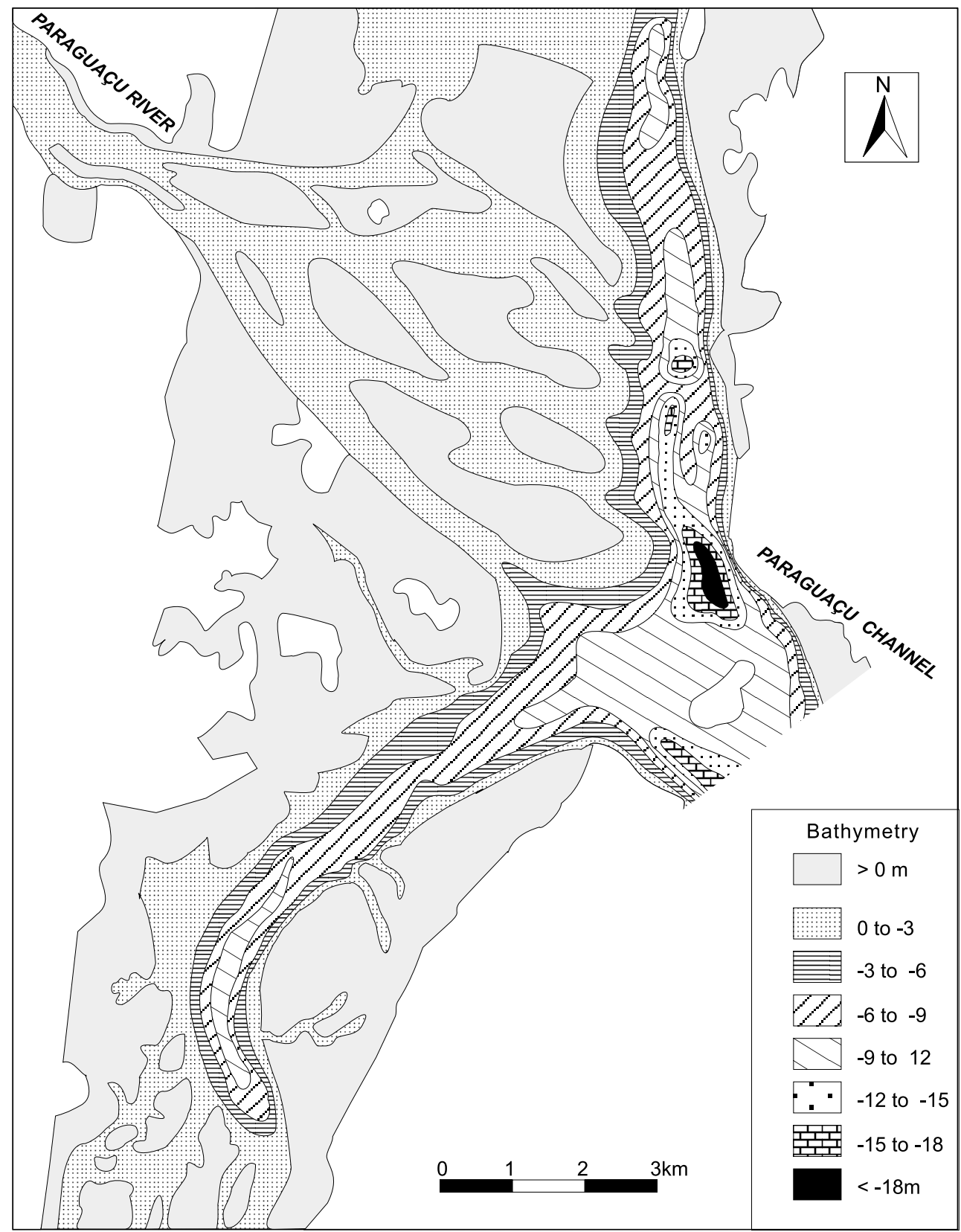

Fig. 3 - General bathymetry of Iguape Bay. The isobath of $0 \mathrm{~m}$ refers to low water level (after Avanzo 1977).

Seismic profiles (Figure 4) were executed in several sections of the bay utilizing an electricacoustic profiler (ELAC) with a frequency of $18 \mathrm{kHz}$ that allows $40 \mathrm{~m}$ of maximum penetration. Depth ranges were 0-48 and 0-96 $\mathrm{m}$.

\section{SURFACE SEDIMENT DISTRIBUTION AND FACIES}

Surface sediment texture within the TSB varies from clay to very coarse sand (Brichta 1977, Bittencourt et al. 1976, Avanzo 1977). A compilation of the surface sediment texture is given in Figure 5, which 


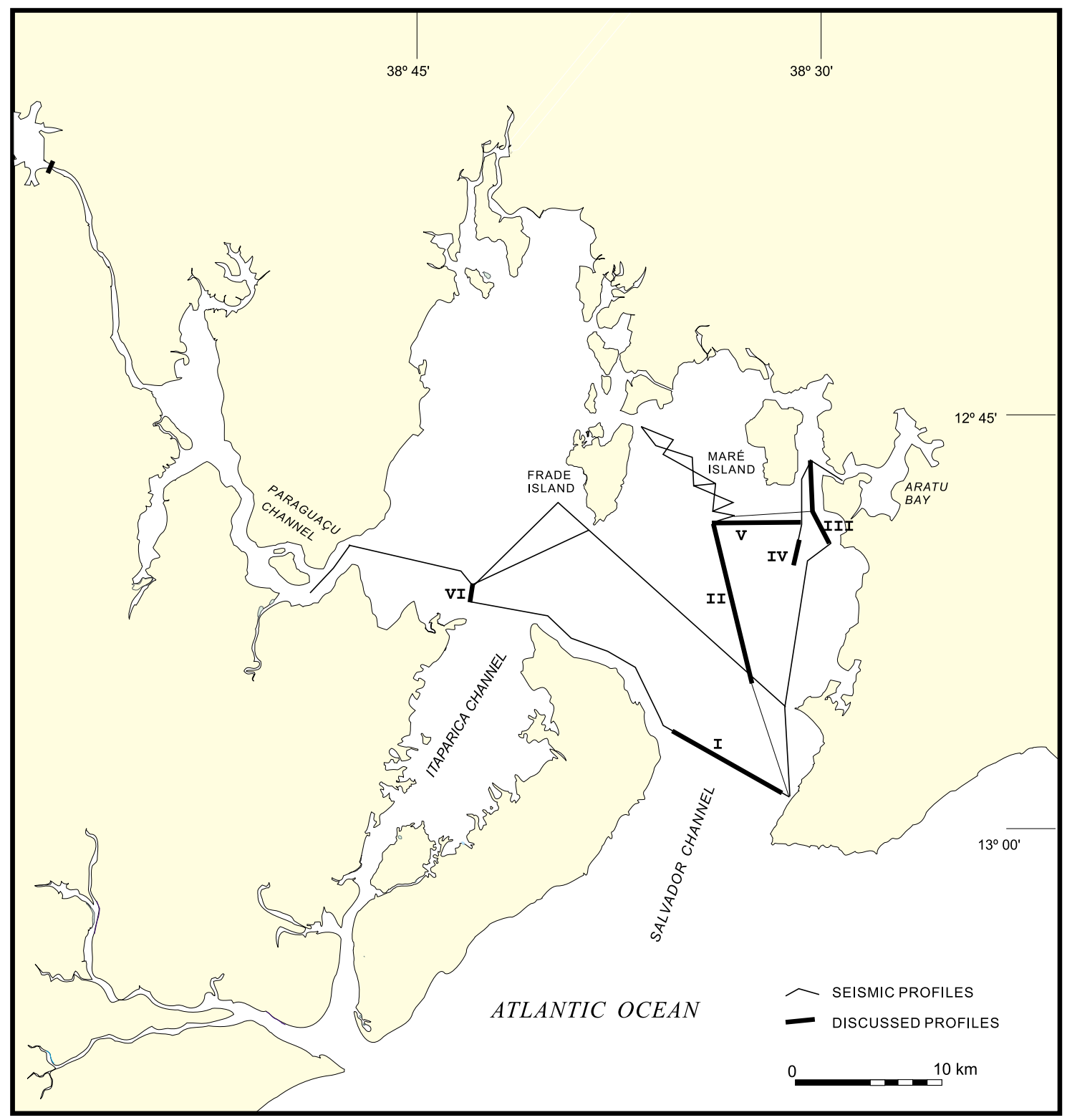

Fig. 4 - Location of the seismic profiling inside the TSB and profiles analyzed in this study.

shows the general distribution of 3 sediment-class sizes based on the Md (Iguape Bay, Avanzo 1977) and $\mathrm{D}_{50}$ (Brichta 1977, Bittencourt et al. 1976). Medium to very coarse sand is observed at the two entrances of the bay, at the exit of Paraguaçu River, along the western margin of Itaparica Channel and around Maré Island, as well as scattered zones within the central part of the bay. Fine to very fine sand occur mainly along Itaparica channel and as a continuous belt across the central part of the bay and along the northwestern margin into Paraguaçu Channel. Mud size sediments characterize most of the northern half of the TSB and Aratu Bay, and is also very conspicuous inside Paraguaçu Channel and at the seaward side of Iguape Bay. Sandy sediments inside Iguape Bay form a large, frictionally- 
dominated delta (Wright 1985), which is now prograding over a deeper, muddy zone at the upstream reaches of Paraguaçu Channel (Figure 3) (the impact of the Pedra do Cavalo dam on the fluvial sediment yield has not yet been assessed).

Based on the sediment texture and composition, Bittencourt et al. (1976) proposed the existence of four surface sedimentary facies inside the central part of the TSB, namely: quartzose sandy facies, muddy facies, carbonate facies and mixed facies (Figure 6). The quartzose-sand facies occur at the northern and southern entrances of the TSB and behind Itaparica Island. They possess, however, different characteristics. Behind Itaparica Island sediment color varies between olive and gray, shows small percentages of carbonate fragments, the grains are sub-angular to sub-rounded and coated with clay, suggesting a non-marine origin. On the other hand, sand deposits from both entrances of TSB display yellow-grayish quartz grains, which are bright, clean and rounded to well rounded, suggesting marine origin. The carbonate facies is gray in color and is largely composed by carbonate fragments (more than $50 \%$ of the weight). These fragments derived mainly from mollusks, equinoderms and Halimeda, and to a smaller degree from corallinaceous algae and foraminifer. Subordinate clay makes always less than $30 \%$ of the total sample weight. The mud facies is composed by more than $50 \%$ of clay and silt, olive-gray in color, with subordinate quartz grains and carbonate fragments. The mixed facies is olive-gray in color, and characterized by a mixture (in different proportions) of quartzose sand, mud and carbonate fragments, with none exceeding more than $50 \%$ of the total sample weight. Overall, all facies' sediments are poorly to badly sorted, with the exception of those within Salvador and Itaparica Channels (Macedo 1977).

The classification of the sedimentary facies above does not account for different sediment origins nor a chronological sequence. As acknowledged by Bittencourt et al. (1976), different morphometric and compositional characteristics of the sediments that constitute the sandy facies suggest different sources. From an evolutionary standpoint, where bays and estuaries are transgressed by marine sediments during a sea level rise and subsequently infilled with continental deposits during a stillstand or sea-level fall (Roy 1984, 1994, Nichols et al. 1991, Dalrymple et al. 1992, Boyd \& Honig 1992, Allen \& Posamentier 1993, Lessa et al. 1998), highstand, transgressive, and regressive sedimentary deposits might be present in the bay bottom. A review of the standing facies classification is therefore proposed, with the differentiation of five surface sedimentary facies as follows: transgressive siliciclastic marine sand facies, transgressive carbonate marine sand facies, transgressive bay sand-mud facies, regressive bay-mud facies and regressive fluvial sand facies (Figure 7).

The transgressive siliciclastic marine sand facies occurs at the entrance of both Itaparica and Salvador channels. It must be associated with landward transport of marine sand into the bay during the last marine transgression. As indicated by Bittencourt et al. (1976), sediments are yellowish-gray in color, composed mainly by clean quartz grains and carbonate detritus (derived mostly from mollusks, Halimeda and briozoas), the latter contributing between $10 \%$ and $50 \%$ to the total sample weight (Macedo 1977). Both quartz grains and the carbonate detritus are sub-rounded to rounded, and the coarsest grain size is above $1 \mathrm{~mm}$ in diameter.

The transgressive carbonate marine sand facies is observed in the vicinity of Maré and Frade Islands. It is mostly composed by rounded to well rounded fragments of mollusks, which makes more than $50 \%$ of the sample weight (fragments of coral, Halimeda, equinoderm and sponge are also observed) (Macedo 1977). It is proposed that this facies is associated with the in situ production of carbonate material, reworked by waves and currents. As will be shown below, carbonate sedimentation is restricted to a somewhat flat platform bordered by slopes with gradients around 1:15, and transport of carbonate sediment from the open bay up this platform seems unlikely. If this hypothesis is true, sediment production might have started soon after 


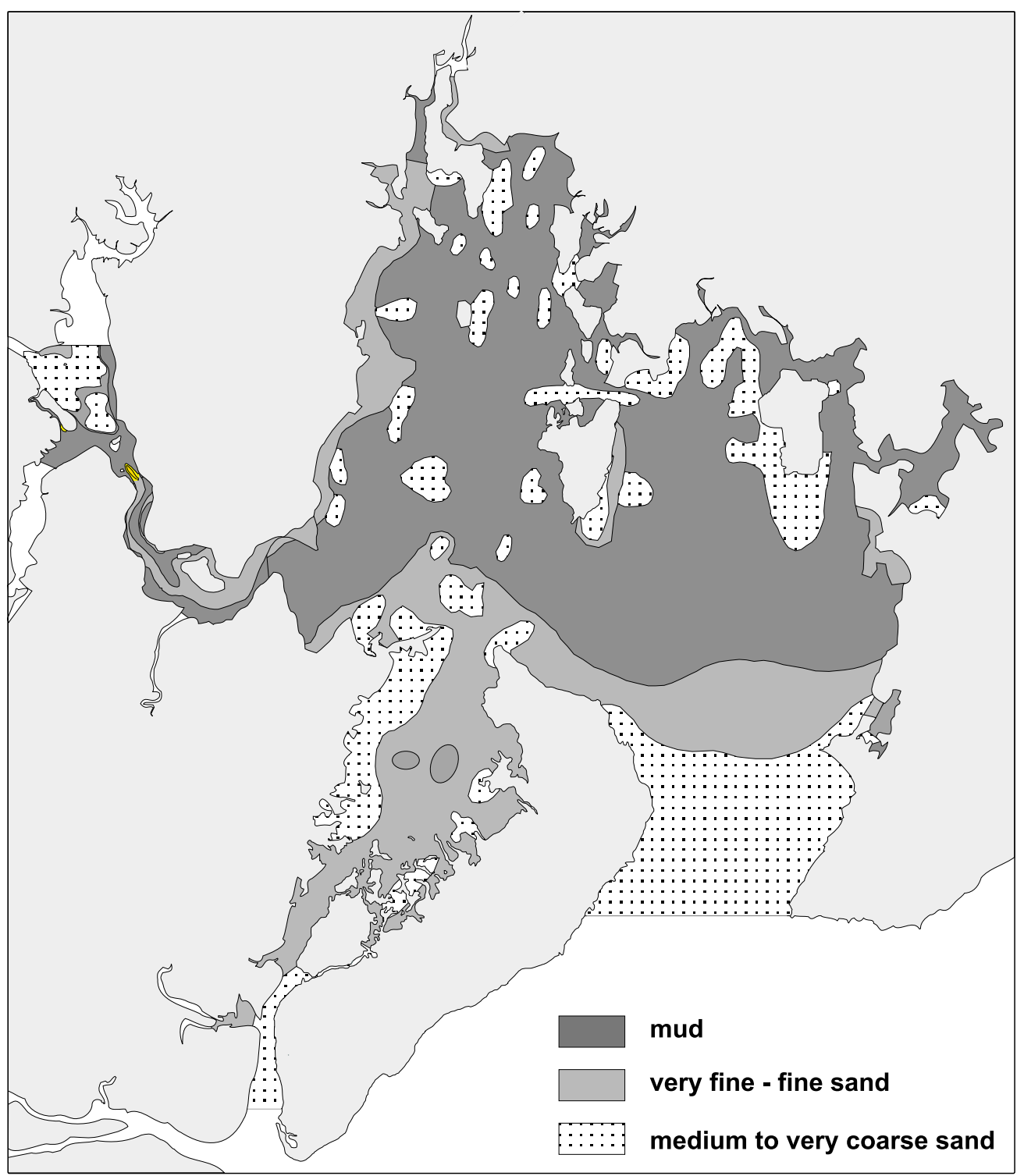

Fig. 5 - Surface sediment size distribution inside the TSB. Data compiled from Bittencourt et al. (1976) $\left(D_{50}\right)$ for the main part of TSB, Brichta (1977) $\left(D_{50}\right)$ for Paraguaçu Channel and from Avanzo (1977) $\left(\mathrm{M}_{\mathrm{d}}\right)$ for Iguape Bay.

the drowning of a shallow substrate (see below) during the Holocene sea-level rise. Reported sedimentation rates associated with Halimeda in coral-reef areas are up to $6 \mathrm{~cm}$ per year (Freile et al. 1995), but much lower rates would be expected inside TSB due to larger water turbidity.

The transgressive bay sand-mud facies is present in the central part of the bay, inside Itaparica Channel and all the way along Paraguaçu Channel and northwestern margin of the bay. Except at Itaparica Channel, the facies is muddy sand, olive-gray in color, constituted by $10 \%$ to $30 \%$ of clay and somewhat immature (sub-angular) quartz grains possessing a film of iron oxide (Brichta 1977, 


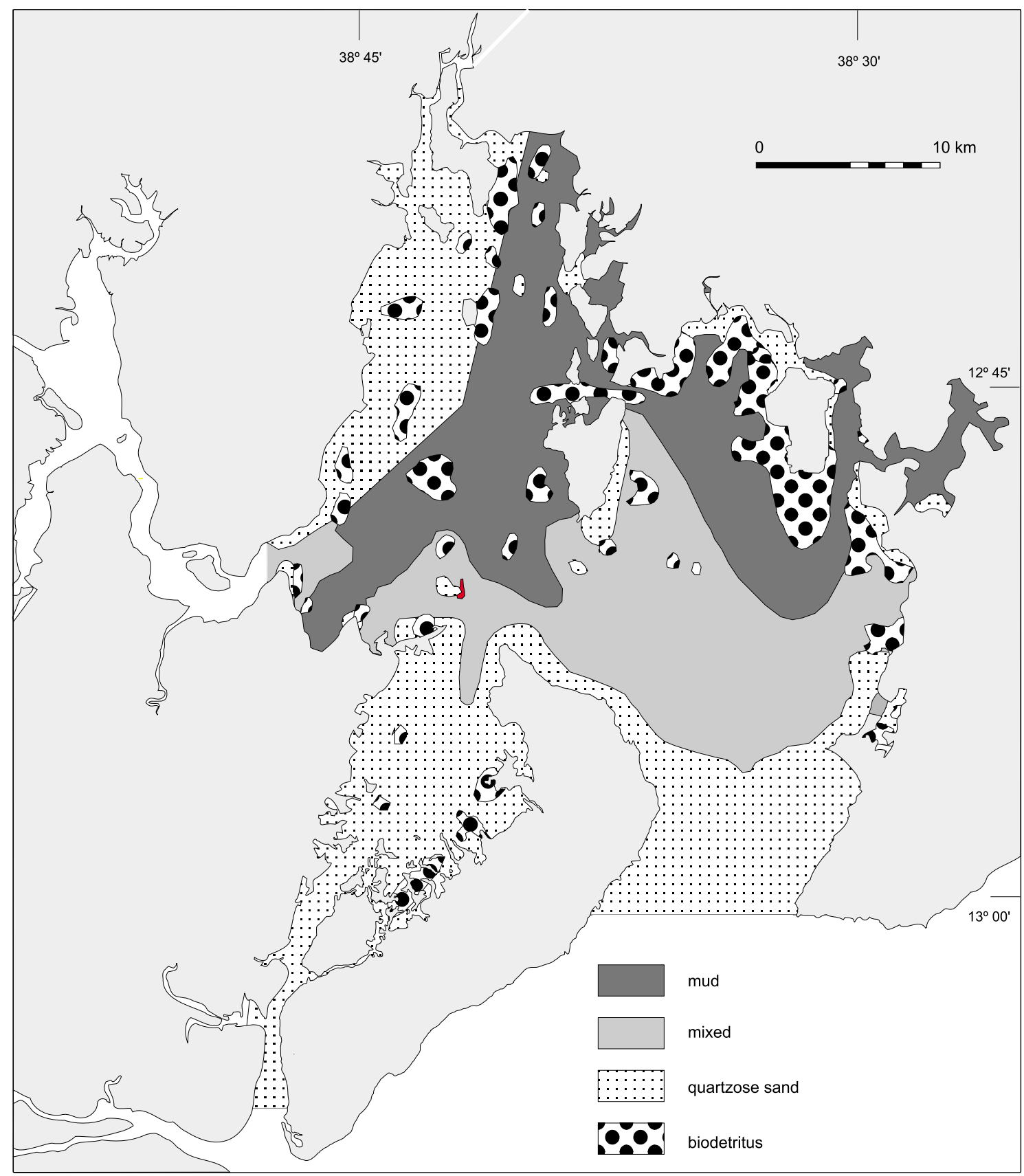

Fig. 6 - Surface sedimentary facies inside the TSB (after Bittencourt et al. 1976).

Macedo 1977). Higher carbonate content, above $75 \%$ per sample weight, is observed in the central part of bay (Bittencourt et al. 1976, Corrêa \& Ponzi 1980), where and is characterized by fragments of Halimeda, mollusks and equinoderms, showing marked signs of transport (Corrêa \& Ponzi 1980). Along the Paraguaçu Channel, carbonate content is less than $15 \%$ and mostly composed by fragments of mollusks (Brichta 1977, Corrêa \& Ponzi 1980). Limonite, hematite, feldspar and micas are also ob- 


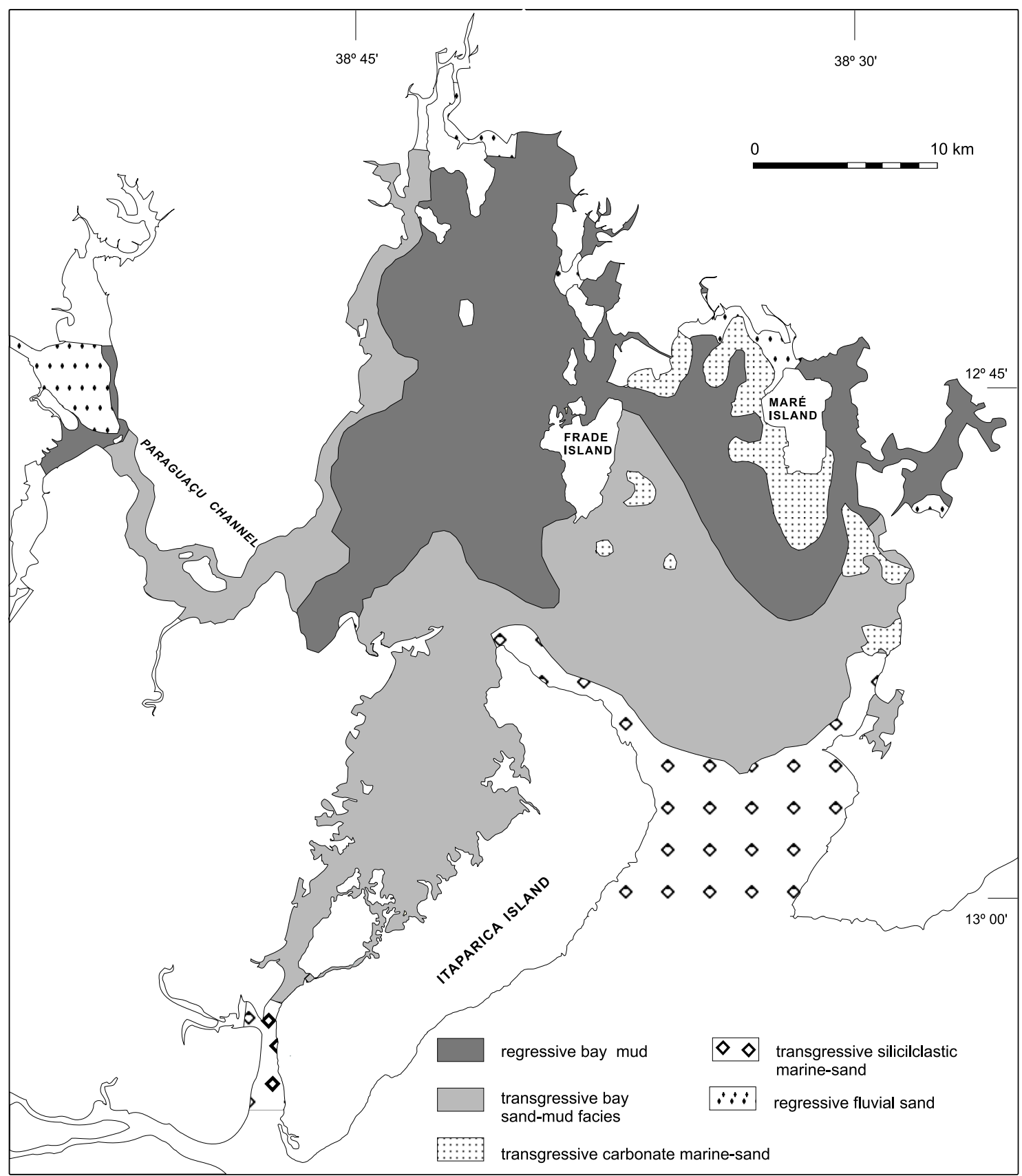

Fig. 7 - Reviewed surface sedimentary facies inside the TSB.

served in samples from Paraguaçu Channel and central part of the bay (Brichta 1977, Avanzo 1977, Macedo 1977), suggesting fluvial provenance of the sediments (Corrêa \& Ponzi 1980). Inside the Itaparica Channel, clay content is less than $10 \%$ and quartz grains are sub-angular to sub-rounded, coated with clay (Bittencourt et al. 1976). The carbonate content is less than $20 \%$, and composed by well rounded fragments mostly of ostracodes, mollusks and equinoderm (Macedo 1977). This facies is pro- 
posed to be associated with the reworking of existing riverine and (upper?) estuarine deposits during the post-glacial marine transgression, and should be regarded as palimpsest. Inside Itaparica Channel, and along the northwestern bay shore, the sediments are more likely to be associated to the reworking of alluvial fan deposits born of Cretaceous sandstones (Sergi Formation, Figure 2).

The regressive bay-mudfacies is silty clay, with less than $10 \%$ of sand (Bittencourt et al. 1976). The carbonate content is generally less than $20 \%$, but may reach more than $50 \%$ locally, in areas previously classified as a biodetritus facies (Figure 6, Bittencourt et al. 1976). Mollusk fragments make the bulk of the carbonate content within the regressive bay-mud facies. Corrêa and Ponzi (1980) suggest that the locally high carbonate content found within the regressive bay-mud facies is related to the outcropping of the transgressive sand-mud facies presently undergoing downlapping. The facies is interpreted as upper bay sediments, delivered by the land drainage within the last 5000 years and with a possible, relatively high contribution of authoctonous carbonate sediments (see discussion below). This facies should be actively prograding over the transgressive sand-mud facies.

The regressive fluvial sand facies is observed inside Iguape Bay, at the outlet of Subaé River and possibly at the small river outlets to the north of Maré Island. Its sediment is poorly to moderately sorted (after Folk \& Ward 1957), with angular to sub-angular grains and less than $5 \%$ of carbonate content (Avanzo 1977). This facies forms a prograding delta in front of Paraguaçu and Subaé rivers, and must be downlaping the regressive bay-mud and the transgressive bay sand-mud facies. A shallower bathymetry at the exit of Subaé River might be preventing the formation of a well defined river delta, as observed inside Iguape Bay (Figure 3).

\section{BAY STRATIGRAPHY}

Out of the several seismic transects inside the bay, six profiles (Figure 4) that best represent the nature of the subsurface sedimentation were chosen to be analyzed in more detail. Profiles 1 and 2 (Figure 8) are characteristic of the bay entrance, where a gradation from sandy to sandy-mud sediments take place (Figure 5). The entrance of the bay shows an irregular topography characterized by a strong acoustic reflector at the surface, suggesting the outcropping of the Cretaceous basement likely covered by sand in the smoother areas. The multiple reflectors in Profile 2 are strong in the southeastern end but fade away into the more horizontal surface inside the bay, where they are replaced by internal reflectors indicating sediment infilling (in the region dominated by the regressive mud bay-mud - see Figure 7). Closer to the northwestern end of Profile 2 (after fine tuning the gain level) some $20 \mathrm{~m}$ of sediment can be observed covering an irregular reflector possibly associated with the Cretaceous basement. The navigation channel that leads to Madre de Deus Island (see Figure 2) is observed at the end of the profile, displaying again a strong reflector suggesting hard bottom. At least two sedimentary units are perceived on top of the deepest reflector at the northwestern extremity of Profile 2 (Figure 10). The upper unit is characterized by internal sub-horizontal reflectors, sub-parallel to the surface, with a maximum thickness of $10 \mathrm{~m}$. The lower unit fills in the paleovalleys, "with" an average thickness of 10 $\mathrm{m}$. The prominent "dent" in the surface topography in the third-quarter of Profile 2 appears to fold down the internal reflectors. This feature has been interpreted by Pasenau and Brichta (1987) as neotectonic in nature.

Profile 3 (Figure 9) borders the channel that leads to Aratu Harbor (see Figure 2). An irregular paleorelief of up to $18 \mathrm{~m}$ deep, or at about $25 \mathrm{~m}$ below mean sea level, form several valleys at the beginning of the profile. These valleys are thought to be associated with a peripheral drainage running east-west. The reflector is possibly related to the Cretaceous basement, and covered here by an average of $15 \mathrm{~m}$ of sediments. Internal reflectors within the sedimentary unit are overall sub-parallel and sub-horizontal to the surface. In the central part of the profile the 

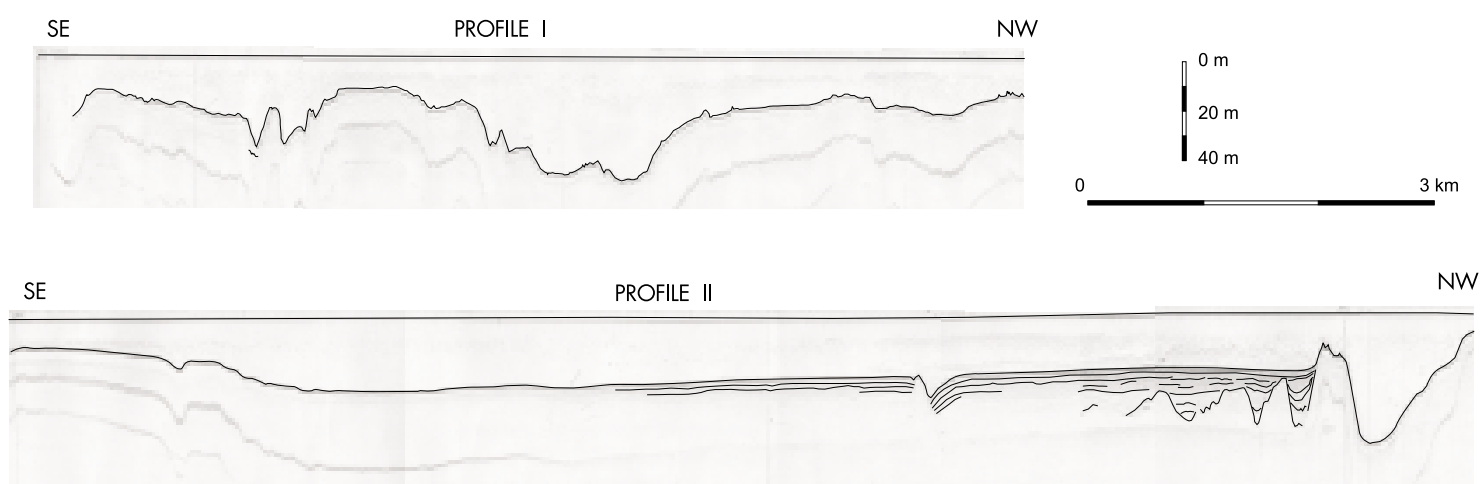

Fig. 8 - Seismic profiles 1 and 2, with internal reflectors and sea bed highlighted for clarity.
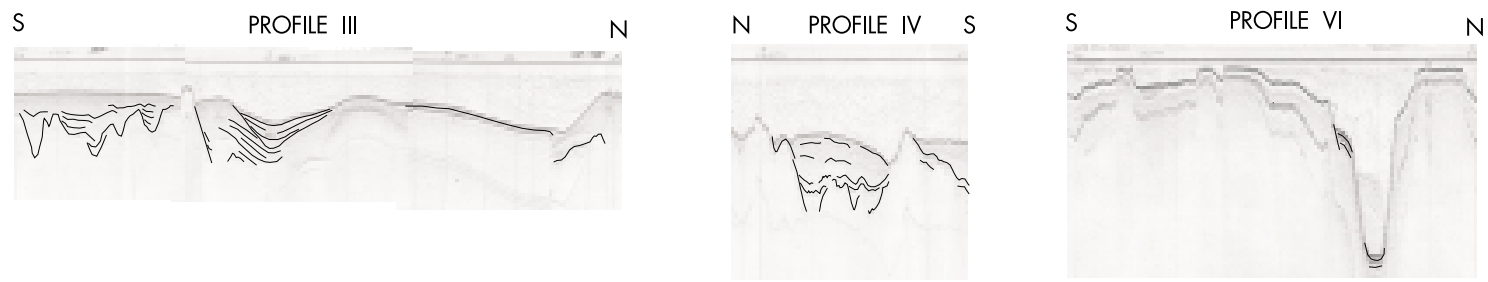

E PROFILE $\vee$

W
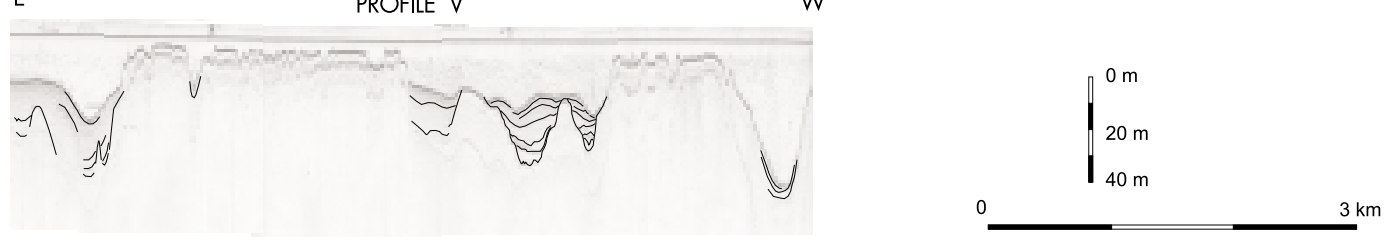

Fig. 9 -Seismic profiles 3, 4, 5, and 6, with internal reflectors and sea bed highlighted for clarity.

reflectors are all internal to a sedimentary unit, and show two generations of channel-fill deposits over $10 \mathrm{~m}$ in thickness each (Figure 10). A reflector associated to a pre-Holocene surface was not detected in this section, which suggests a deeper paleo-valley. As the topography descends towards the north, a strong reflector (see the multiples beneath) parallel to the surface appears at about $1 \mathrm{~m}$ below the bay bed. A similar reflector, which occasionally reaches the surface, prevails in the profile that run towards Paraguaçu channel and in the profiles between Itaparica and Frade islands (Figure 4). Although no coring evidence exists, it is possible that this reflector is associated with a shell layer. At the end of Profile 3, a topographical rise appears to be associ- ated with almost $20 \mathrm{~m}$ of sediment accumulation at the exit of Aratu Bay channel (Figure 4). Sedimentation at this site might be ascribed to the confluence of the water flows that ebb from Aratu Bay and the area east of Maré Island.

Profile 4 (Figure 9) is also marginal to the channel leading to Aratu Harbor, opposite to Profile 3. A well defined reflector, possibly associated with the Cretaceous basement, crops out at the surface and shows east-west orientated paleovalleys underlying up to 30 of sediment fill. As in Profile 2, at least two sedimentary units can be observed (Figure 10). The upper unit has an average thickness of $15 \mathrm{~m}$ and is characterized by sub-parallel internal reflectors which are sub-horizontal to the surface. The 


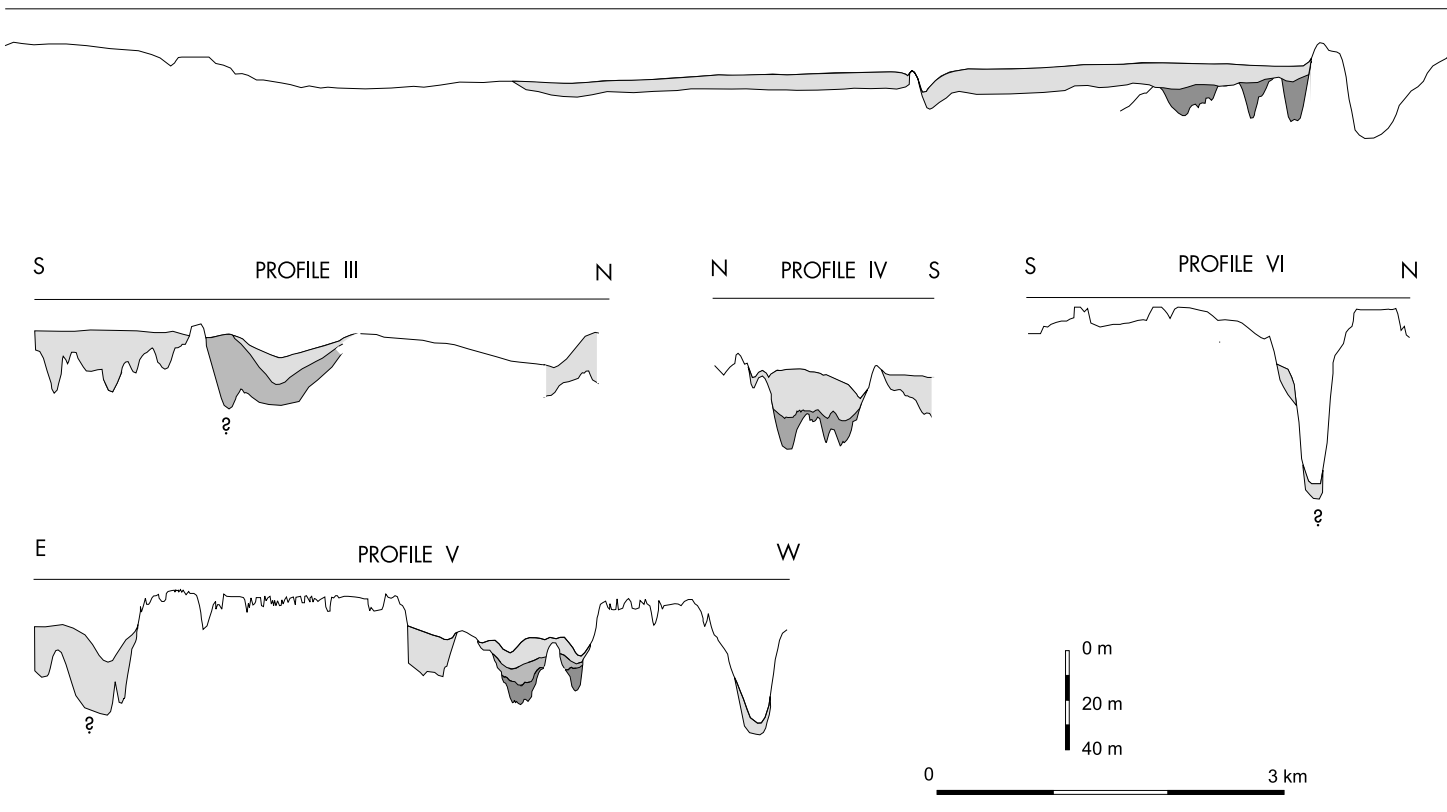

Fig. 10 - Interpretation of the seismic profiles with possible sedimentary units.

lower unit, with uneven internal reflectors, fills in the paleovalleys and attain a maximum thickness of about $10 \mathrm{~m}$.

Profile 5 (Figure 9) is a transect between the channels that lead to Madre de Deus Island and Aratu Bay, crossing a plateau that extends to the south of Mare Island. A flat, shallow, hard (see multiples beneath), and very irregular surface prevails in the profile. Prior to the mid 1970's this surface was covered with shelly sediments (transgressive carbonate sand - Figure 7) that were dredged as row material for cement production. Removal of the sediment exposed the topographical unevenness that is possibly associated with a karst surface developed on a Pleistocene coral-reef structure. Shallower paleovalleys, cut into what appears to be the Cretaceous basement, are observed in the center of the profile. Whereas only one, $18 \mathrm{~m}$ thick sedimentary unit appears to fill in the eastern most paleovalley, the reflection patterns suggest the existence of three sedimentary units at the western ones (Figure 10). Given the reflection characteristics, the upper and lower sedimentary units are equivalent to those identified in
Profiles 1 and 3 (Figure 10).

The channel leading to Aratu Harbor, at the eastern end of Profile 4, is underlain by a $20 \mathrm{~m}$ thick sediment package, which sits on top of an irregular basement reflector as deep as the present channel at the opposite (western) side of the profile. Internal to the sedimentary unit, the reflectors suggest the gradual accretion of a paleochannel which is likely related to the Aratu Bay paleodrainage. The western channel, leading to Madre de Deus Island, shows only $5 \mathrm{~m}$ of sediment accumulation (Figure 10), suggesting either that the strength of the tidal flow has diminished little since the bay was flooded or that a tidal diastem (Lessa et al. 1998) is presently active along the channel.

Profile 6 (Figure 9) is located in the western side of the bay, between Medo Island and Pedras Shoal (Figure 1). It is observed that the whole profile is irregular, acoustically hard (see multiple signals), except for two small sectors at the shoulder and at the bottom of the narrow valley, where about $5 \mathrm{~m}$ of sediment accumulation has occurred. This valley is likely related to the paleochannel of Paraguaçu 
River, here attaining a depth $60 \mathrm{~m}$ below mean sea level. Worth noting is a possible change in water density that appears to exist in the lower half of the channel, which would suggest a saltier layer and little mixing of the water column.

\section{DISCUSSION AND CONCLUSION}

The geologic framework of the TSB has been determined, to a high extend, by tectonism. Although the major fault systems were established in the Cretaceous, reactivations occurred in the Tertiary and Quaternary, as indicated by several studies (King 1956, Tricart \& da Silva 1968, Martin et al. 1986, Bittencourt et al. 1999). Vertical displacements in the order of meters during the Holocene (Martin et al. 1986) and historical records of earthquakes (Branner 1920), attest for the continuing adjustment of the basement beneath the bay. Such tectonic bearing appears to obscure the evidence of fluvial erosion that has likely occurred throughout the bay during successive lowstand episodes. For instance, the paleodrainage of the Paraguaçu River is not easily followed inside the bay and the closest canyon on the shelf (Salvador Canyon) is located some $50 \mathrm{~km}$ to the south of Salvador. Paleochannels, apparently with a E-W orientation and relief in the order of $20 \mathrm{~m}$, are observed in profiles 2, 3 and 4 (Figure 9), suggesting a drainage orientation normal to the expected one (given the $\mathrm{N}-\mathrm{S}$ direction of the present-day valleys in the area). Also, no major fluvial stream, that could give rise to these buried valleys, is observed today in the nearby area. As indicated by Tricart and da Silva (1968), the drainage basin that presently converge to the bay is still in embryo.

Despite this apparently significant tectonic control on the sedimentation of the TSB, and the paucity of subsurface geological data, it is still possible to fit the observed sedimentary facies distribution into generalized models for sedimentation in incised valley systems in wave-dominated coasts (Dalrymple et al. 1992, Allen \& Posamentier 1993, Roy 1994, Zaitlin et al 1994). In these models, a succession of a marine, estuarine and fluvial facies exists, with the extent of each individual facies (and their role in the infilling process of the estuary) being dictated by the distribution of energy (wave, tide and river) along the estuary, the estuary's entrance condition (whether or not there is restriction imposed by a sandy barrier), and the fluvial sediment yield. A departure of the facies distribution of the TSB in relation to the models above is the existence of an apparently extensive palimpsest facies (transgressive bay sand-mud facies, Figure 7).

Figure 11 shows a schematic representation of this distribution of the relative energy along the bay, up to Paraguaçu and Subaé rivers, along with the distribution of the surface sedimentary facies (see also Lessa et al. in press). Tidal current velocities up to $1.20 \mathrm{~m} / \mathrm{s}$ have been measured at the bay entrance, waning towards the center of the bay (east of Frade Island, Figure 1) where maximum velocities are about $0.5 \mathrm{~m} / \mathrm{s}$ during spring tides (Lessa et al. in press). Wave action appears to be significant only in the eastern half of the bay, as indicated by the distribution of beach deposits. The main rivers debouching into the bay possess small discharges and their influence would then be restricted to few kilometers downstream (in the case o Paraguaçu River, floods prior to damming might have been felt as far as the seaward end of Paraguaçu channel - Figure 1). The sedimentary facies distribution would follow, somewhat closely, the changes in the relative energy suggested for the bay. The large and unobstructed entrance of the TSB allows for full tidal ranges and a more energetic environment inside, as compared to bays and estuaries with a depositional barrier in front that allows for the existence of a quiet, central basin (Dalrymple et al. 1992).

In the TSB, the upper sedimentary unit, capping the acoustic basement and other lower sedimentary units, is apparently associated with the regressive bay-mud facies identified in Figure 7. The seismic profiles show the existence of at least 2 sedimentary units underlying this facies and overlying a basement (Cretaceous?). Because there is no data on the nature of these sedimentary units, it is difficult to evaluate their nature. In a very tentative interpre- 

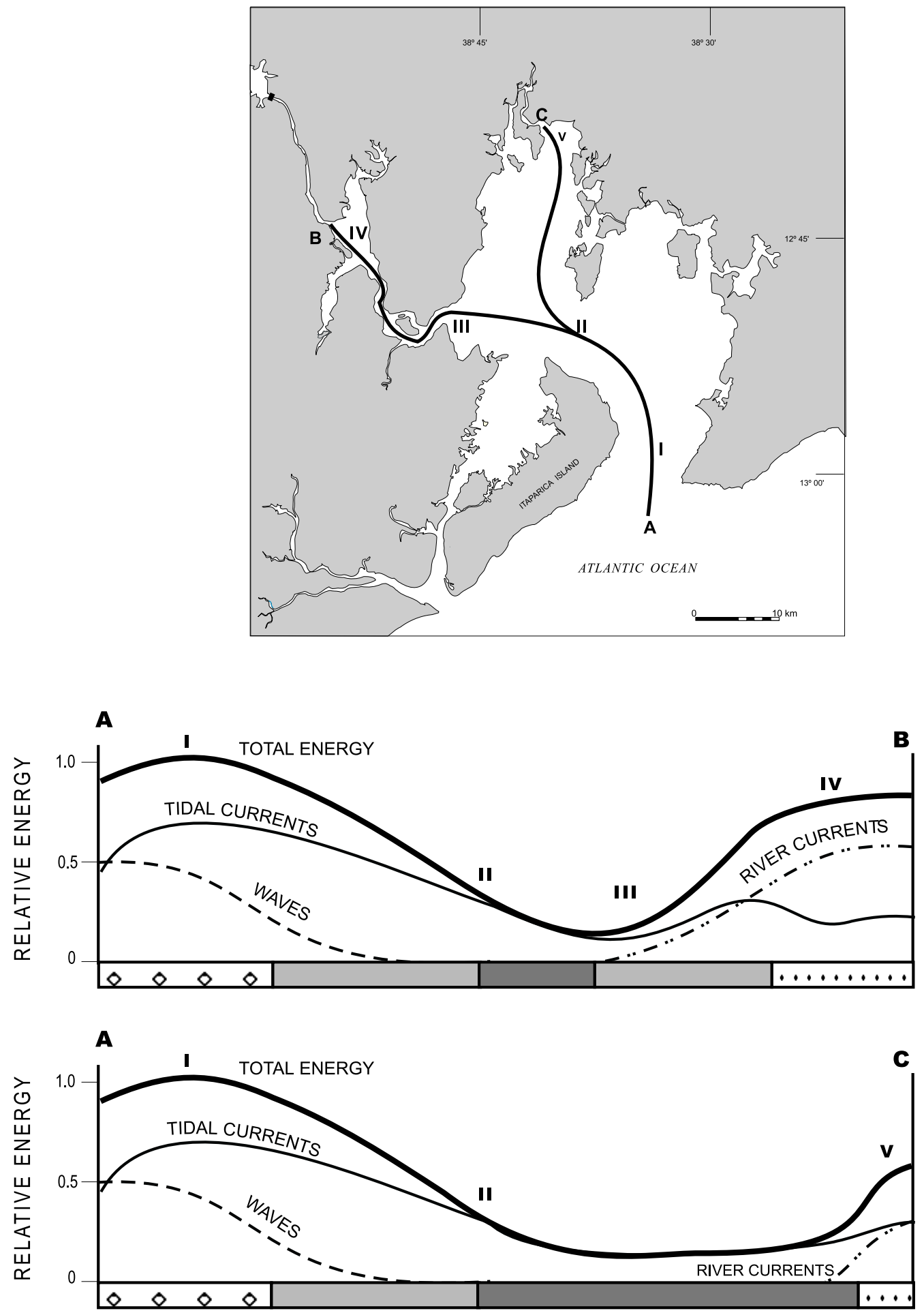

Fig. 11 - Schematic distribution of the energy level and sedimentary facies along the main axis of the TSB and along Paraguaçu Channel and Paraguaçu River. See legend for sedimentary facies in Figure 7. 
tation, we suggest that the lower unit in profiles 2, 4 and 5 (Figure 10) is pre-Holocene and possibly related to fluvial deposits laid down during the last lowstand(s). The intermediate sedimentary unit in Profile 4 could be associated with a transgressive system tract (Van Wagoner et al. 1988), and could still be of Holocene age. The lower unit in Profile 3 (Figure 10), is apparently associated with a recent process of channel fill, as suggested by its outcropping, and could be related to the sedimentation of the regressive bay-mud facies.

Assuming that the regressive bay-mud facies accounts for all of the topmost seismic unit, it would have been deposited after the last post-glacial sea level maximum, or within the last 5,000 years. Knowing that the thickness of the upper sedimentary unit in the analyzed profiles varies between 5 $\mathrm{m}$ and $20 \mathrm{~m}$, sedimentation rates associated with the regressive bay-mud zone would have varied from $0.8 \mathrm{~mm} / \mathrm{y}$ to $4 \mathrm{~mm} / \mathrm{y}$, averaging $2.4 \mathrm{~mm} / \mathrm{y}$. This number similar to present-day rates of sediment accretion assessed with ${ }^{210} \mathrm{~Pb}$ for the same area of the bay, which are in the order of $1.5 \mathrm{~mm} / \mathrm{y}$ (Roberto Argolo, Instituto de Física UFBA, pers. commun.). The sedimentation rate likely undergone by the TSB during the Holocene is also comparable to those observed in Guanabara and Paranaguá bays during the Holocene, which are likewise associated with the deposition of a regressive bay-mud facies. In Guanabara Bay, Amador (1980) found sedimentation rates around $1.5 \mathrm{~mm} / \mathrm{y}$ for the last 5,000 years (it is worth mentioning is that recent sedimentation rates is in the order of $10^{3} \mathrm{~mm} / \mathrm{y}$ due to deforestation and land use within the catchment area-Amador 1980). Implicit in the data of Lessa et al. (1998), the upper half of Paranaguá Bay might have experienced siltation of about $1,0 \mathrm{~mm} / \mathrm{y}$ in the mid- to late-Holocene.

As suggested by Corrêa and Ponzi (1980), locally high carbonate content within the regressive bay-mud facies, between Frade Island and Paraguaçu Channel, would be related to "windows" exposing the underlying, carbonate rich transgressive sand-mud facies. The physical characteristics of the carbonate fraction, showing evident signs of trans- port, supports such conjecture. However, the seismic profiles show a strong reflector, possibly associated with shell layers, extending continuously at about $1 \mathrm{~m}$ below the surface of the regressive mud facies and cropping out locally. If the reflector marks the boundary between the transgressive and regressive facies, then only $1 \mathrm{~m}$ of the regressive bay-mud facies would have accumulated in most of the area between Frade Island and Paraguaçu Channel (Figure 1). This is contrasting to the apparently much larger sediment accumulation associated with the regressive bay-mud facies observed in the northeastern part of the bay. We therefore suggest that at least part of the carbonate sediments apparently underlying the regressive bay-mud facies could be autochthonous.

\section{ACKNOWLEDGMENTS}

We are thankful to Ben Clennell for his help with the interpretation of the seismic profiles. G. Lessa, A. Bittencourt and J. Dominguez are under a research scholarship from the Brazilian Research Council $(\mathrm{CNPq})$.

\section{REFERENCES}

Allen GP \& Posamentier HW. 1993. Sequence stratigraphy and facies model of an incised valley fill: the Gironde estuary, France. J Sed Pet 63: 378-392.

Amador ES. 1980. Assoreamento da Baía de Guanabara - taxas de sedimentação. An Acad Bras Ci 52(4): 723-742.

Angulo RJ \& Lessa GC. 1997. The Brazilian sea level curves: a critical review with emphasis on the curves from Paranaguá and Cananéia regions. Mar Geol 140: $141-166$.

Araújo TMF, LeÃo ZMAN \& Lima OAL. 1984. Evolução do recife de coral da Ilha de Itaparica determinada a partir de dados geológicos e geofísicos. In: XXXIII Congresso Brasileiro de Geologia, 1. Rio de Janeiro. Proceedings ..., Rio de Janeiro: SBG, 1984. p. 159-169.

Avanzo PE. 1977. A sedimentação no setor central da Baía de Maragogipe - Bahia. Salvador, 85 p. 
(Dissertação de Mestrado, Universidade Federal da Bahia).

Barreto MAS \& PAREdes JF. 1995. Estudos hidrodinâmicos no estuário do Rio Paraguaçu. Ciência e Tecnologia 5: 46-51.

BARros FC. 1977. Estudo dos sedimentos biogênicos das enseadas dos Tainheiros e do Cabrito. Salvador, 76p. (Dissertação de Mestrado, Universidade Federal da Bahia).

Bittencourt ACSP \& Vilas Boas GS. 1977. Ocorrência de chamosita nos sedimentos recentes da Baía de Aratu. Rev Bras Geoci 7(4): 230-238.

Bittencourt ACSP, Brichta A \& Di Napoli E. 1974. A sedimentação na Baía de Aratu. Rev Bras Geoci 4(1): 51-63.

Bittencourt ACSP, Dominguez JML \& UsSAmi N. 1999. Flexure as a tectonic control on the large scale geomorphic characteristics of the eastern Brazil coastal zone. J Coast Res 15(2): 505-519.

Bittencourt ACSP, Ferreira YA \& Di Napoli E. 1976. Alguns aspectos da sedimentação na Baía de Todos os Santos. Rev Bras Geoci 6(4): 246-263.

Boyd R \& Honig C. 1992. Estuarine sedimentation on the eastern shore of Nova Scotia. J Sed Pet 62(4): $569-583$

Branner JC. 1920. Recent earthquakes in Brazil. Bull Seism Soc Am 10(2): 90-104.

Brichta A. 1977. A sedimentação na foz do Rio Paraguaçu. Salvador, 113p (Dissertação de Mestrado, Universidade Federal da Bahia).

CePlaB (Centro de Planejamento da Bahia). 1979. Bacias Hidrográficas do Estado da Bahia. Séries Recursos Naturais. Salvador: Governo do Estado da Bahia. 190 p.

CORRÊA ICS \& Ponzi VRA. 1980. Estudo dos carbonatos associados aos sedimentos de fundo da parte oeste da Baía de Todos os Santos. An Acad Bras Ci 52(2): 347-352.

DALrymple RW, Zaitlin BA \& Boyd R. 1992. Estuarine facies models: conceptual basis and stratigraphic implications. J Sed Pet 62(6): 1130-1146.
FOLK RL \& WARD WC. 1957. Brazos River bar: a study in the significance of grain size parameters. $\mathrm{J} \mathrm{Sed} \mathrm{Pet}$ 27(1): 3-26.

Freile D, Milliman JD \& Hills L. 1995. Leeward bank margin Halimeda meadows and draperies and their sedimentary importance on the western Great Bahama Bank slope. Coral Reefs 14: 27-33.

KING LC. 1956. Geomorfologia da Região Oriental do Brasil. Rev Bras Geogr 2: 37-72.

LEÃo ZMAN. 1971. Um depósito conchífero do fundo da Baía de Todos os Santos próximo à Laje do Ipeba. Salvador, 56p. (Dissertação de Mestrado, Universidade Federal da Bahia).

LeÃo ZMAN \& BitTencourt ACSP. 1977. A fração biodetrítica dos sedimentos de fundo da Baía de Aratu (BA). Rev Bras Geoc 7(2): 115-130.

LEÃo ZMAN \& BRICHTA A. 1996. A plataforma continental. In: BARBosA JSF \& DomingueZ JML (Ed.); Texto explicativo para o Mapa Geológico do Estado da Bahia - Escala 1:1.000.000, SME, Salvador. p. 185-198.

LeÃo ZMAN, Muniz Ferreira MTG \& Araujo TMF. 1982. Sedimentologia e estruturas biogênicas do recife de franja da Ilha de Itaparica, Bahia. In: XXXII Congresso Brasilerio de Geologia, Roteiro de Excursão, Salvador. Proceedings ..., Salvador: SBG, 1982. p. 201-299.

LessA GC \& ANGulo RJ. 1998. Oscillation or not oscillation: that's the question - Reply. Mar Geol 150: 189-196.

Lessa GC, Dominguez JML, Bitencourt ACSP \& Brichta A. The Tides and Tidal Circulation of Todos os Santos Bay, Northeast Brazil: a general characterization. Anais da Academia Brasileira de Ciências (in press).

Lessa GC, Meyers S \& Marone E. 1998. Holocene stratigraphy in the Paranaguá Bay estuary, south Brazil. J Sed Res 68(6): 1060-1076.

MACEdo MHF. 1977. Estudo sedimentológico da Baía de Todos os Santos. Salvador, 75p. (Dissertação de Mestrado, Universidade Federal da Bahia).

Machado AJ. 1977. Estudo dos sedimentos recentes $e$ 
dos foraminíferos da Praia de Inema. Salvador, 76

p. (Dissertação de Mestrado, Universidade Federal da Bahia).

Martin L, Bittencourt ACSP, Flexor JM, Suguio K \& Dominguez JML. 1986. Neotectonic movements on a passive continental margin: Salvador region, Brazil. Neotectonics 1(1): 87-103.

Martin L, Bittencourt ACSP, Dominguez JML, FleXor JM \& Suguio K. 1998. Oscillations or not oscillations: that is the question. Mar Geol 150: 179-187.

Martin L, Dominguez JML \& Bittencourt ACSP. 1999. Reavaliação das variações do nível relativo do mar ao longo do litoral leste e sudeste brasileiro: idades calendárias e informações adicionais. In: VII Congresso AssociaÇão Brasileira de Estudos do Quaternário, Proceedings..., Porto Seguro: ABEQUA, 1999. viiabequa_zco001.pdf.

Medeiros RA \& Ponte FC. 1981. Roteiro geológico da Bacia do Recôncavo, Bahia. Salvador. PETROBRÁS/SEPES/DIVEN/Setor de Ensino na Bahia. $63 \mathrm{p}$.

Mestrinho SSP. 1998. Estudo do comportamento geoquímico dos metais pesados nos sedimentos da região estuarina do Rio Paraguaçu - BA. São Paulo, 158p. (Tese de Doutorado, Universidade de São Paulo).

Nascimento AP. 1977. Estudo sedimentológico das enseadas dos Tainheiros e do Cabrito. Salvador. 58 p. (Dissertação de Mestrado, Universidade Federal da Bahia).

Nichols MM, Johnson GH, \& Peebles PC. 1991. Modern sediments and facies model for a microtidal coastal plain estuary, the James River Estuary, Virginia. J Sed Pet 61(6): 883-899.

Pasenau HG \& Brichta A. 1987. Possibilidades interpretativas de estruturas tectono-sedimentares a partir de perfilagem eletro-acústica. I SimpósIo NacionaL de Estudos Tectônicos, Proceedings..., Salvador: UFBA, 1987. p. 27-29.
Roy PS. 1984. New South Wales estuaries: their origin and evolution. In: Tном BG (Ed.); Coastal Geomorpholgy in Australia. Sydney: Academic Press, p. 99-121.

Roy PS. 1994. Holocene estuary evolution - stratigraphic studies from southeastern Australia. Incised-valley Systems: Origin and Sedimentary Sequences. SEPM Special Pub 51: 241-263.

Tricart J \& Da Silva TC. 1968. Estudos de Geomorfologia da Bahia e Sergipe. Fund. Desenv. Ci na Bahia, Salvador, $167 \mathrm{p}$.

Van Wagoner JC, Posamentier HW, Mitchum RM, VAIL PR, SARG JF, Loutit TS \& HaRdenbol J. 1988. An overview of the fundamentals of sequence stratigraphy and key definitions. In: WILGUS CK et al. (Ed.); Sea-Level Changes: An Integrated Approach. SEPM Special Publication 42, p. 39-45.

Vilas Boas GS \& Bittencourt ACSP. 1979. Química e Mineralogia da fração argilosa dos sedimentos do fundo da Baía de Todos os Santos, Bahia. Rev Bras Geoci 9(3): 179-197.

Vilas Boas GS \& Nascimento MAM. 1979. Evolução paleogeográfica e paleoclimática da região das enseadas dos Taineiros e do Cabrito, Bahia, nos últimos 5000 anos. Rev Bras Geoci 9: 159-168.

Wolgemuth KM, Burnett WC \& Moura PL. 1981. Oceanography and suspended material in Todos os Santos Bay. Rev Bras Geoci 11(3): 172-178.

Wright D. 1985. River Deltas. In: Davis R (Ed.); Coastal Sedimentary Environments. New York: Springer Verlag, p. 3-76.

Zaitlin BA, Dalrymple RW \& Boyd R. 1994. The stratigraphic organization of incised valley systems associated with relative sea-level change. In: DALRYMPLE R \& BOYD R (Ed.); Incised-valley Systems: Origin and Sedimentary Sequences. SEPM Special Publication 51, p. 265-283. 